\title{
General practice based psychosocial interventions for supporting carers of people with dementia or stroke: a systematic review
}

\author{
Nan Greenwood", Ferruccio Pelone and Anne-Marie Hassenkamp
}

\begin{abstract}
Background: Particularly with ageing populations, dementia and stroke and their resultant disability are worldwide concerns. Much of the support for people with these conditions comes from unpaid carers or caregivers. The carers' role is often challenging and carers themselves may need support. General practice is often the first point of contact for people with these conditions and their carers, making it potentially an important source of support. This systematic review therefore synthesised the available evidence for the impact of supportive interventions for carers provided in general practice.

Methods: PRISMA guidelines were adopted and the following databases were searched: MEDLINE; EMBASE; the Cochrane Library; PsycINFO; CINAHL Plus; Applied Social Sciences Index and Abstracts and Healthcare Management Information Consortium.

Results: Two thousand four hundred eighty nine results were identified. Four studies, involving 447 carers, fitted the inclusion criteria. Three of these came from the United States of America. None investigated supportive interventions for carers of people with stroke. Primarily by the provision of information and educational materials, the interventions focussed on improving carer mental health, dementia knowledge, caregiving competence and reducing burden, difficulties and frustrations. Overall the evidence suggests that these interventions may improve carer well-being and emotional health but the impact on physical health and social variables was less clear. However, the diversity of the carer outcomes and the measures used means that the findings must be viewed with caution.

Conclusions: Unpaid carers pay an essential role in caring for people with stroke and dementia and the dearth of literature investigating the impact of supportive interventions for these carers of is surprising. The available evidence suggests that it may be possible to offer support for these carers in general practice but future research should consider focussing on the same outcome measures in order to allow comparisons across interventions.
\end{abstract}

Keywords: Carer, Caregiver, General practice, Stroke, Dementia, Psychosocial intervention

\section{Background}

Stroke and dementia result in both long and short term disability $[1,2]$ and worldwide both are major health and social care issues. However, with ageing populations and the move away from institutional care, the numbers of people living in the community with dementia [3] or post-stroke disability [4] are rising. Although clearly very different, stroke and dementia are both long-term

\footnotetext{
* Correspondence: nan.greenwood1@gmail.com

Faculty of Health, Social Care and Education, Kingston University and St George's, University of London, London, UK
}

conditions whose impact goes far beyond the individuals with the condition.

Stroke is recognised as the major cause of complex long-term disability in adults worldwide [5]. After hospitalisation and rehabilitation approximately $80 \%$ of stroke survivors return home with much of their care provided by families [6, 7]. However, undertaking this role is known to have negative consequences for these unpaid carers $[8,9]$. The picture for dementia is very similar to stroke with unpaid family carers providing most of the support for people with dementia living at 
home [3, 10], with similar challenges faced by carers across countries and care systems [11]. However, research shows that carers of people with dementia frequently have poorer physical and emotional health than carers of people with other long-term conditions $[12,13]$.

Over the past decade there have been several studies evaluating and reviewing the evidence for the impact of support interventions for family carers of community dwelling relatives. Existing reviews of interventions intended to support family carers have focused mostly on dementia [14-17] with relatively few looking at interventions for carers of people with stroke $[4,18]$. By and large these reviews have concentrated on particular types of interventions (e.g. information provision, psychosocial or educational interventions), or particular outcomes (e.g. burden or quality of life). Overall the evidence for the effectiveness of these interventions is mixed but some studies suggest a positive impact of, for example, information provision [18] and psycho-education on, for example, carer depression and problem-solving [19].

General practice teams are often the first point of contact for services for carers making them well placed to recognise and support carers of people with all health conditions including stroke and dementia [20-22]. Evidence for stroke, for example, suggests that both stroke survivors and their carers want regular contact with their general practitioners (GPs) [23] whilst some later research suggests that GPs and other members of primary care teams believe they have an important role to play in supporting carers but lack time and resources to do so [24].

However, to the best of our knowledge, there is no systematic review looking at interventions offered in general practice to support carers. Therefore, the aim of this systematic review is to identify, appraise and summarise all the published evidence on general practice based interventions to support carers of people with stroke or dementia.

This review was based upon the following specific questions:

1) What interventions are offered by general practice to support carers of people with dementia or stroke?

2) What are the most effective general practice based interventions to support carers of people with dementia or stroke?

3) What are the implications for future research in this area?

\section{Methods}

The review followed PRISMA guidelines [25], and the protocol was registered with PROSPERO the international prospective register of systematic reviews at the Centre for Reviews and Dissemination, University of York; registration number CRD42015016056 [26].

\section{Search strategy}

The following electronic databases were searched: MEDLINE; EMBASE; the Cochrane Library; PsycINFO; CINAHL Plus; Applied Social Sciences Index and Abstracts; Healthcare Management Information Consortium. A Medline search strategy (Table 1) was developed and was modified where necessary to run on the other databases.

Searches were from database inception to December 2014 (an updated search was undertaken in July 2015) and was limited to articles written in English.

The electronic database search was supplemented by three strategies: 1) manual screening of the reference lists of any previous similar reviews; 2) manual screening of the reference lists of included studies; 3 ) and handsearching of two relevant journals focusing on general practice and dementia/stroke for relevant publications over the last 10 years.

\section{Inclusion criteria and study selection}

Studies of any design were considered if they fitted the following inclusion criteria:

- Population: Carers of people with dementia (including relatives, spouses and friends) and/or carers of people with stroke/stroke survivors (including relatives, spouses and friends).

- Intervention: Any non-pharmacological intervention delivered by healthcare providers from general practice (e.g. GPs, practice nurses) aimed to improve carer outcomes: e.g. educational interventions, skills training interventions, psychological interventions, counselling and information provision.

- Setting: General practice, which includes healthcare providers who are "primarily responsible for the provision of comprehensive and continuing care to every individual seeking medical care irrespective of age, sex and illness' [27].

- Outcomes: e.g. carer mental health (including psychological well-being, depression, and anxiety), carer competency (including coping strategies, knowledge of dementia, self-efficacy and responses to disruptive behaviour) and carer burden.

- Study characteristics: Studies were included if they reported empirical findings and outcomes regardless of their study design. This included quantitative, qualitative and mixed methods studies

Articles were excluded if they did not fulfil one or more inclusion criteria or if they were literature reviews, case series, case studies, commentaries, not peer-review 
Table 1 MEDLINE (OVID) search strategy: inception to 2014 (updated in July 2015)

\begin{tabular}{|c|c|c|}
\hline ID & Concept & Search $($ Hits $=n)$ \\
\hline 1 & General practice & $\begin{array}{l}\text { (General practice\$ or General } \\
\text { practitioner\$ or GPs).tw. (40707) }\end{array}$ \\
\hline 2 & & $\begin{array}{l}\text { (family practice\$ or family } \\
\text { practitioner } \$ \text { or family physician\$ } \\
\text { family medicine\$).tw. (4097) }\end{array}$ \\
\hline 3 & & $\begin{array}{l}\text { (district nurse\$ or practice } \\
\text { nurse\$).tw. (3976) }\end{array}$ \\
\hline 4 & & $\begin{array}{l}\text { (community NEAR/3 health).tw. } \\
\text { (18269) }\end{array}$ \\
\hline 5 & & $\begin{array}{l}\text { (community NEAR/3 care).tw. } \\
\text { (8627) }\end{array}$ \\
\hline 6 & & $\begin{array}{l}\text { (community NEAR/3 services).tw. } \\
(4750)\end{array}$ \\
\hline 7 & & exp Primary Health Care/ (62263) \\
\hline 8 & & exp Family Practice/ (32389) \\
\hline 9 & & exp Physicians, Family/ (9205) \\
\hline 10 & & exp General Practitioners/ (2116) \\
\hline 11 & & exp General Practice/ (36336) \\
\hline 12 & & $\begin{array}{l}1 \text { or } 2 \text { or } 3 \text { or } 4 \text { or } 5 \text { or } 6 \text { or } 7 \text { or } \\
8 \text { or } 9 \text { or } 10 \text { or } 11(146870)\end{array}$ \\
\hline 13 & Carers & $\begin{array}{l}\text { (informal NEAR/5 (care-giver\$ or } \\
\text { caregiv\$ or carer\$)).tw. (1718) }\end{array}$ \\
\hline 14 & & $\begin{array}{l}\text { (family NEAR/5 (care-giver\$ or } \\
\text { caregiv\$ or carer\$)).tw. (5332) }\end{array}$ \\
\hline 15 & & $\begin{array}{l}\text { (spouse\$ NEAR/5 (care-giver\$ or } \\
\text { caregiv\$ or carer\$)).tw. (602) }\end{array}$ \\
\hline 16 & & $\begin{array}{l}\text { (relative\$ NEAR/5 (care-giver\$ or } \\
\text { caregiv\$ or carer\$)).tw. (829) }\end{array}$ \\
\hline 17 & & $\begin{array}{l}\text { (parent\$ NEAR/5 (care-giver\$ or } \\
\text { caregiv\$ or carer\$)).tw. (2222) }\end{array}$ \\
\hline 18 & & $\begin{array}{l}\text { (brother\$ NEAR/5 (care-giver\$ or } \\
\text { caregiv\$ or carer\$)).tw. (5) }\end{array}$ \\
\hline 19 & & $\begin{array}{l}\text { (sister\$ NEAR/5 (care-giver\$ or } \\
\text { caregiv\$ or carer\$)).tw. (5) }\end{array}$ \\
\hline 20 & & exp Caregivers/ (19868) \\
\hline 21 & & $\begin{array}{l}13 \text { or } 14 \text { or } 15 \text { or } 16 \text { or } 17 \text { or } 18 \\
\text { or } 19 \text { or } 20(23437)\end{array}$ \\
\hline 22 & Stroke \& Dementia & exp Alzheimer Disease/ (53196) \\
\hline 23 & & exp Lewy Body Disease/ (2092) \\
\hline 24 & & $\begin{array}{l}\text { exp Dementia, Vascular/ or exp } \\
\text { Dementia, Multi-Infarct/ or exp } \\
\text { Dementia/ or exp Frontotemporal } \\
\text { Dementia/ (89101) }\end{array}$ \\
\hline 25 & & dement\$.tw. (50486) \\
\hline 26 & & exp Stroke/ (77056) \\
\hline 27 & & $\begin{array}{l}\text { Cerebrovascular Disorders/ } \\
\text { (12999) }\end{array}$ \\
\hline 28 & & $\begin{array}{l}\text { (cva or cerebrovascular or } \\
\text { cerebral vascular or stroke\$ or } \\
\text { brain vasc\$).tw. (130119) }\end{array}$ \\
\hline
\end{tabular}

Table 1 MEDLINE (OVID) search strategy: inception to 2014 (updated in July 2015) (Continued)

\begin{tabular}{ll}
\hline 29 & $\begin{array}{l}22 \text { or } 23 \text { or } 24 \text { or } 25 \text { or } 26 \text { or } 27 \\
\text { or } 28 \text { (248841) }\end{array}$ \\
$30 \begin{array}{l}\text { General practice based } \\
\text { interventions for carers of } \\
\text { people with stroke or dementia }\end{array}$ & $\begin{array}{l}12 \text { and } 21 \text { and } 29 \text { (491) } 30 \text { to (English language and } \\
\text { humans) (445) }\end{array}$ \\
\hline
\end{tabular}

articles and/or unpublished. After duplicate removal, a two-step selection process was performed: a) Title and abstract screening; 2) Full-text screening. All records identified were independently reviewed by two reviewers (NG and $\mathrm{AMH}$ ). Abstracts were assessed and full texts of studies not excluded at this stage, were retrieved for further evaluation. Discrepancies were resolved by discussion or when necessary were decided by the third reviewer (FP).

\section{Data extraction}

Two reviewers (NG and AMH) independently extracted the data from selected papers, with any disagreement resolved by the third author (FP). A checklist was used to extract the following information from the selected papers:

- General information, for example, year of publication, reported study type, research objective/aim(s)

- Descriptive information, for example, description of the intervention (including setting, time period, frequency, and intervention duration); study population characteristics (including relevant demographic characteristics, inclusion/exclusion criteria, participant numbers); outcomes measured and data analysis

- Study quality

- Results including findings and the reported discussion \& conclusions.

\section{Assessment of methodological quality}

The quality of included studies was appraised using the quality checklists for quantitative and qualitative studies [28]. The broad nature of the quality assessment allows a range of methodologies to be assessed. For the quantitative studies, 14 items were scored depending on the extent to which the specific criteria were met ("yes" $=2$, "partial" =1, "no" =0). Items not applicable to a particular study design were marked " $\mathrm{n} / \mathrm{a}$ " and were excluded from the calculation of the summary score.

\section{Data synthesis}

A meta-analysis was not performed due to the heterogeneity of the included studies. Therefore, narrative synthesis was conducted. 


\section{Results}

The electronic searches retrieved a total of 2489 results. As shown in Fig. 1, 29 full-text articles were reviewed against the inclusion criteria leading to the selection of four for narrative synthesis. Additional file 1 provides references list of the 25 excluded studies in the last stage of the screening process.

All selected studies evaluated general practice based interventions for carers of people with dementia and none investigated support for carers of people with stroke (Table 2). Three studies included carers of people with Alzheimer's disease and related dementias [29-31]. The remaining study [32] included carers of people with dementia and carers of people with a mixture of other chronic disorders (e.g. heart disease and musculoskeletal disorders). Carer participant sample sizes ranged from 31 [31] to 164 [29]. In total, 447 carer participants were included in the four studies. The maximum reported attrition rate was $57 \%$ [29]. Carers were mostly female with a mean age of between 61 and 72 years.

Three papers originated from the USA [29-31] with one from Spain [32]. They were published between 2003 and 2014. The settings were community and primary care facilities [29-32]. Only one study was a home based primary care program [30].

\section{Methodological quality}

Two out of the four included studies were randomised controlled trials (RCT) using pre and post intervention measures [29, 32]. One study [31] used a 'non-equivalent control group trial'. In this quasi-experimental trial, a pretest-posttest controlled design was used. Here the assignment to intervention and control groups was nonrandom and, as a result, the groups may have been different prior to the study (i.e. non-equivalent control group trial). This study compared the intervention with the comparison group using three-point time measures (baseline; 6 months and 12 months after baseline). The remaining study [30] was described as a clinical translation of the REACH II RCT [33] but could also be described as an uncontrolled before and after study. There was no control group but there was comparison between baseline and 6-month follow-up.

The quality ratings of the included studies ranged from $58 \%$ [30] to $93 \%$ [29], with two studies rated as good quality ( $85 \%$ or more), as illustrated in Table 3. A clear study question was stated in all studies. Furthermore, all studies reported their findings in detail and formulated appropriate conclusions. Baseline and or demographic information were clearly provided except in Nichols et al. [30]. Whilst the attrition rate was reported in all studies, intention-to-treat analysis was only

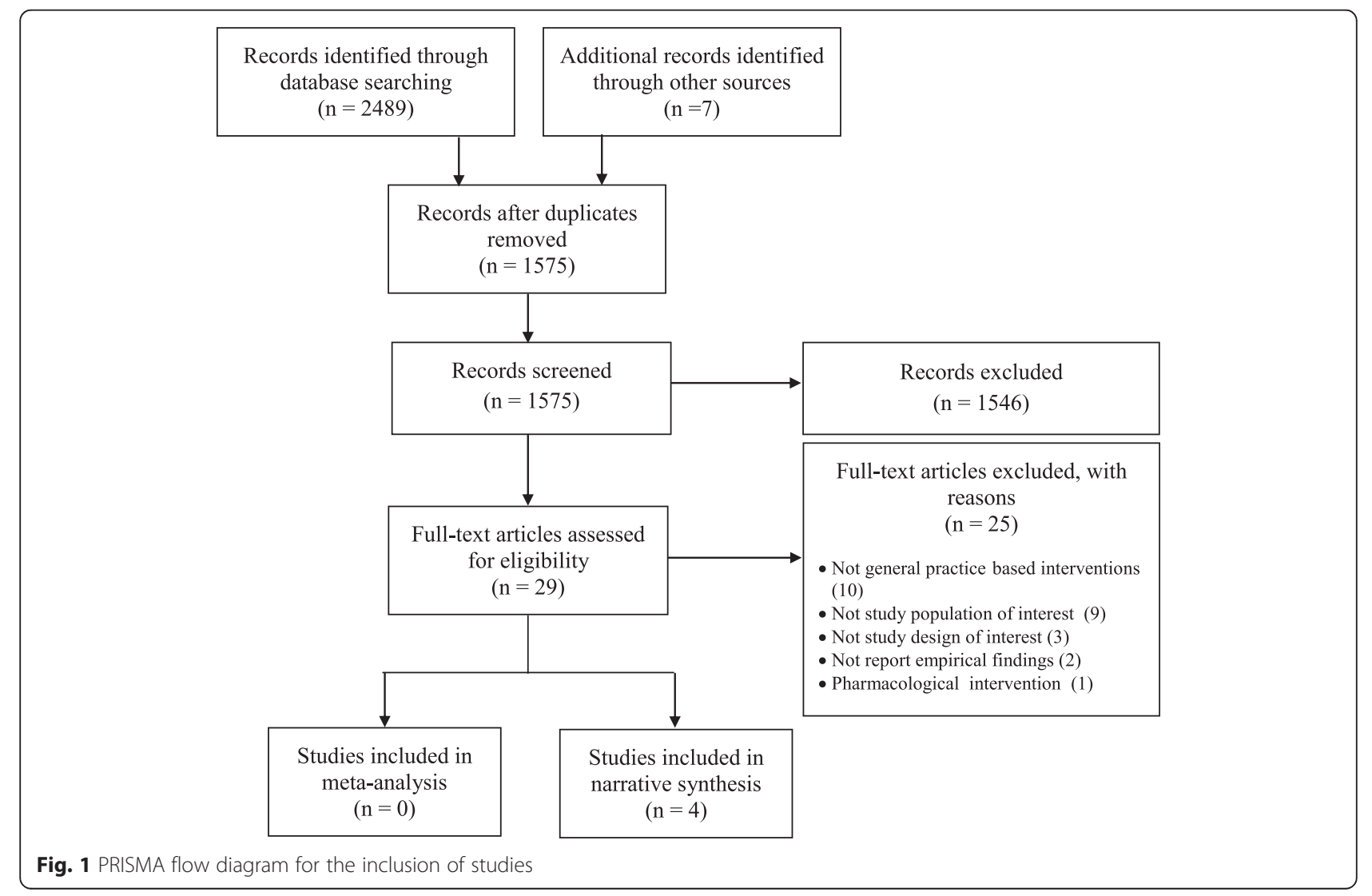


Table 2 Summary characteristics of included papers

\begin{tabular}{|c|c|c|c|c|c|c|}
\hline \multirow[t]{3}{*}{ Reference } & \multirow[t]{3}{*}{ Country Setting } & \multirow[t]{3}{*}{ Methods and intervention } & \multicolumn{4}{|l|}{ Carer participants } \\
\hline & & & $\begin{array}{l}\text { 1) Intervention } \\
\text { group }\end{array}$ & $\begin{array}{l}\text { Number* } \\
\text { (Attrition \%) }\end{array}$ & $\begin{array}{l}\text { Age } \\
\text { (years) }\end{array}$ & $\begin{array}{l}\text { Gender } \\
\% \text { female }\end{array}$ \\
\hline & & & \multicolumn{2}{|l|}{ 2) Control group } & \multicolumn{2}{|l|}{$\begin{array}{l}\text { mean } \\
(\mathrm{SD})\end{array}$} \\
\hline \multirow[t]{2}{*}{$\begin{array}{l}\text { Burns et } \\
\text { al., [29] }\end{array}$} & USA & \multirow{2}{*}{$\begin{array}{l}\text { This RCT tested two 24- month primary care } \\
\text { interventions to alleviate the psychological distress } \\
\text { of carers of people with AD. The interventions, using } \\
\text { targeted educational materials, were a) patient behaviour } \\
\text { management only (behaviour care) (A), and b) A + carer } \\
\text { stress-coping management. }\end{array}$} & 1) Enhanced care & $\begin{array}{l}82 \\
(52.4 \%)\end{array}$ & $\begin{array}{l}65.1 \\
(12.6)\end{array}$ & $87.4 \%$ \\
\hline & PC sites & & $\begin{array}{l}\text { 2) Behaviour } \\
\text { management }\end{array}$ & $\begin{array}{l}82 \\
(56.5 \%)\end{array}$ & $\begin{array}{l}64.5 \\
(13.0)\end{array}$ & $84.6 \%$ \\
\hline \multirow[t]{2}{*}{$\begin{array}{l}\text { Nichols } \\
\text { et al., [30] }\end{array}$} & USA & \multirow{2}{*}{$\begin{array}{l}\text { This clinical translation was developed to test/demonstrate } \\
\text { that a proven behavioural intervention for carers of PWD } \\
\text { (Belle et al., [33]) could be successfully translated into clinical } \\
\text { practice with different types of staff delivering the 6-month } \\
\text { REACH VA intervention. This included education, support, } \\
\text { and skills training to address five caregiving risk areas: safety, } \\
\text { social support, problem behaviours, depression, and carer } \\
\text { health. There was no control group. }\end{array}$} & $\begin{array}{l}\text { 1) REACH VA } \\
\text { intervention }\end{array}$ & $\begin{array}{l}127 \\
(22.8 \%)\end{array}$ & $\begin{array}{l}71.6 \\
(11.6)\end{array}$ & $92.7 \%$ \\
\hline & $\begin{array}{l}\text { Home-based PC } \\
\text { programs }\end{array}$ & & n.a. & & & \\
\hline \multirow[t]{2}{*}{$\begin{array}{l}\text { Fortinsky } \\
\text { et al., [31] }\end{array}$} & USA & \multirow{2}{*}{$\begin{array}{l}\text { This quasi-experimental study investigated the value of employing } \\
\text { a nurse practitioner with geropsychiatric expertise to augment care } \\
\text { from primary care physicians for PWD and their family carers. The } \\
\text { intervention was called PPDC. Control group patients and carers } \\
\text { received usual care supplemented by educational materials. }\end{array}$} & 1) PPDC program & $\begin{array}{l}21 \\
(23.2 \%)\end{array}$ & $\begin{array}{l}67.4 \\
(13.8)\end{array}$ & $48.0 \%$ \\
\hline & $\begin{array}{l}\text { Community- } \\
\text { based PCP } \\
\text { group practice }\end{array}$ & & 2) Usual care & $\begin{array}{l}10 \\
\text { (n.r.) }\end{array}$ & $\begin{array}{l}69.9 \\
(14.9)\end{array}$ & $70.0 \%$ \\
\hline \multirow[t]{2}{*}{$\begin{array}{l}\text { Rodriguez- } \\
\text { Sanchez } \\
\text { et al., [32] }\end{array}$} & Spain & \multirow{2}{*}{$\begin{array}{l}\text { In a primary health care context, this multicentre } \mathrm{RCT} \text { tested the } \\
\text { effect of a cognitive behavioural intervention developed to } \\
\text { improve the mental health of carers of PWD. The control group } \\
\text { received usual care. }\end{array}$} & $\begin{array}{l}\text { 1) Cognitive- } \\
\text { behavioural } \\
\text { intervention }\end{array}$ & $\begin{array}{l}83 \\
(7.2 \%)\end{array}$ & $\begin{array}{l}61.1 \\
(11.9)\end{array}$ & $73.5 \%$ \\
\hline & PHC centres & & 2) Usual care & $\begin{array}{l}42 \\
(19.0 \%)\end{array}$ & $\begin{array}{l}649 \\
(11.8)\end{array}$ & $76.2 \%$ \\
\hline
\end{tabular}

$A D$ Alzheimer's disease, $P C$ Primary care, $P P D C$ Proactive Primary Dementia Care, $R C$ Trandomized controlled trial, $R E A C H$ VA Enhancing Alzheimer's Caregiver Health (Department of Veterans Affairs), PWD people with dementia

Table 3 Quality assessment of the selected studies

\begin{tabular}{|c|c|c|c|c|c|}
\hline \multirow{2}{*}{\multicolumn{2}{|c|}{ Quality Item [28] }} & \multicolumn{4}{|l|}{ Reference } \\
\hline & & \multirow{2}{*}{$\begin{array}{l}\begin{array}{l}\text { Burns } \\
\text { et al., [29] }\end{array} \\
\text { Yes }\end{array}$} & \multirow{2}{*}{$\begin{array}{l}\begin{array}{l}\text { Nichols } \\
\text { et al., [30] }\end{array} \\
\text { Yes }\end{array}$} & \multirow{2}{*}{$\begin{array}{l}\begin{array}{l}\text { Fortinsky } \\
\text { et al., [31] }\end{array} \\
\text { Yes }\end{array}$} & \multirow{2}{*}{$\begin{array}{l}\text { Rodriguez- } \\
\text { Sanchez et al. } \\
\text { [32] } \\
\text { Yes }\end{array}$} \\
\hline 1 & Question / objective sufficiently described? & & & & \\
\hline 2 & Study design evident and appropriate? & Yes & Yes & Yes & Yes \\
\hline 3 & $\begin{array}{l}\text { Method of subject/comparison group selection or source of information/input variables } \\
\text { described and appropriate? }\end{array}$ & Yes & Yes & Partial & Yes \\
\hline 4 & Subject (and comparison group, if applicable) characteristics sufficiently described? & Yes & Yes & Partial & Yes \\
\hline 5 & If interventional and random allocation was possible, was it described? & Yes & N/A & N/A & Yes \\
\hline 6 & If interventional and blinding of investigators was possible, was it reported? & Yes & Partial & N/A & No \\
\hline 7 & If interventional and blinding of subjects was possible, was it reported? & Partial & No & N/A & No \\
\hline 8 & $\begin{array}{l}\text { Outcome and (if applicable) exposure measure(s) well defined and robust to } \\
\text { measurement / misclassification bias? Means of assessment reported? }\end{array}$ & Yes & Partial & No & Yes \\
\hline 9 & Sample size appropriate? & Yes & Yes & Partial & Yes \\
\hline 10 & Analytic methods described/justified and appropriate? & Yes & Partial & Partial & Yes \\
\hline 11 & Some estimate of variance is reported for the main results? & Yes & Yes & Yes & Yes \\
\hline 12 & Controlled for confounding? & Partial & Yes & No & Yes \\
\hline 13 & Results reported in sufficient detail? & Yes & Yes & Yes & Yes \\
\hline 14 & Conclusions supported by the results? & Yes & Yes & Yes & Yes \\
\hline \multicolumn{2}{|c|}{ Overall quality score } & $93 \%$ & $58 \%$ & $81 \%$ & $86 \%$ \\
\hline
\end{tabular}


used by Fortinsky et al., [31] and Rodriguez-Sanchez et al. [32]. The most important flaw identified within the included studies related to the lack of participant/investigator blinding with only Burns et al. [29] reporting that researchers involved in the study were blinded to intervention assignment. However, findings from this study are likely to be distorted by 'contamination bias' (carers in the control group were exposed to part of the intervention) [34].

\section{Outcome measures}

The included studies investigated the effects of the interventions upon a number of carer outcomes including depression and or depressive symptoms [29-32]; caregiving difficulties and frustrations [29, 30, 32]; carer knowledge of dementia [29-31]; burden [30-32]; time spent providing care [30]; social support [30]; quality of life [32]; well-being [29]; physical health [30] and mental health [32]. These outcomes were measured in a variety of ways making comparison of the findings difficult (Table 4). For instance, two of the three studies [30, 32] reporting on carer burden measured it with the Zarit Burden Interview [35], while Fortinsky et al. [31] measured it with the Short Zarit Burden Interview [36].

A summary of findings showing the impact of the interventions on specific outcomes for each included study is provided in Table 4. There is evidence that interventions in general practice settings consistently produce positive benefits for carers of people with dementia in terms of improved psychological well-being, burden, and depressive symptoms. For example, the primary care educational-intervention investigated in Burns et al. [29] is likely to be effective in reducing carer distress and burden in the management of the person with dementia (by increasing carer ability to manage problem behaviours and therefore increasing their competency and confidence) [29]. The community-based intervention (Proactive Primary Dementia Care - PPDC) examined by Fortinsky et al. [31] did not measurably improve burden, community support service use self-efficacy, depressive symptoms, and symptom management selfefficacy in people with dementia or their carers compared to those in the control group [31]. These authors included an education, a support and skills training component to address five caregiving risk areas: safety, social support, problem behaviours, depression, and carer health. However, following the implementation of the intervention in the REACH VA study [30] carers reported significantly improved outcomes including burden, depression, impact of depression on daily life, and caregiving frustrations. The cognitive behavioural intervention investigated by Rodriguez-Sanchez et al. [32] appears promising. Following the intervention, the carers reported significant improvements in their mental health which appeared to have its effect by reducing their dysfunctional thoughts.

\section{Discussion}

To the best of our knowledge this is the first review identifying, appraising and summarising the literature relating to support for carers of people with dementia in general practice. PRISMA standards were adopted making the search strategy extensive, rigorous and reproducible. The four included studies were international and between them included many participants potentially giving these overall findings more weight. Study design varied but all investigated psychosocial interventions for carers of people with dementia with none focussing on carers of stroke survivors. The insights gained from these studies may help to set future research and service evluation agendas.

The interventions identified here were intended to improve carer emotional health, carer knowledge of dementia, caregiving competence and to reduce carer burden, difficulties and frustrations. They are therefore similar in content and intended outcome to the interventions offered in other community settings and likewise the evidence for their effectiveness is mixed $[4,17,18]$. In the context of general practice, our evidence suggests that the implementation of psychosocial interventions may improve well-being and mental health by improving carers' ability to cope with the behavioural manifestations of the disease and their dysfunctional thoughts about caregiving [29, 32]. Overall the evidence for the impact for these interventions should be treated with caution for three reasons. Firstly, when looking at the effects on burden, quality of life and health status, the impact was not statistically significant. Secondly, when looking at depression, knowledge of illness and caregiving competence, the reported effects were contradictory across studies. Finally, although Nichols et al. [30] reported a significant effect on caregiving frustration, this study scored poorly on methodological quality. Furthermore, the diversity of the outcomes and in the measurement tools used made cross-study comparison difficult.

Earlier reviews [13, 37] also concluded that psychosocial interventions for carers of people with dementia can reduce carer burden. Similarly, our review suggests that psychosocial interventions provided in general practice can have a positive impact on burden, although the findings here were not statistically significant [31, 32]. Only Nichols et al. [30] reported a statistically significant improvement in burden.

Despite its frequent use as an outcome measure, the concept of carer burden is increasingly being questioned 
Table 4 Findings reported in included studies

\begin{tabular}{|c|c|c|c|c|}
\hline \multirow[t]{2}{*}{ Reference } & \multirow{2}{*}{$\begin{array}{l}\text { Type of study } \\
\text { Quality score }\end{array}$} & \multicolumn{2}{|l|}{ Outcomes measures } & \multirow[t]{2}{*}{ Effect } \\
\hline & & Outcome & Measurement tool & \\
\hline \multirow[t]{4}{*}{$\begin{array}{l}\text { Burns et } \\
\text { al., [29] }\end{array}$} & \multirow[t]{2}{*}{$\mathrm{RCT}$} & Affect & CES-D & $\begin{array}{l}\text { Significant positive changes in the CES-D over time }(p=0.007) \text {, } \\
\text { with no significant differences between the intervention and } \\
\text { control groups }(p=0.311)\end{array}$ \\
\hline & & $\begin{array}{l}\text { Response to the } \\
\text { behavioural } \\
\text { manifestations of the } \\
\text { disease }\end{array}$ & RMBPC & $\begin{array}{l}\text { Significant positive changes in RMBPC scores over time }(p=0.010) \text {, } \\
\text { with no significant differences between the intervention and } \\
\text { control groups ( } p=0.976)\end{array}$ \\
\hline & \multirow[t]{2}{*}{$93 \%$} & Risk of depression & CES-D $>16$ & $\begin{array}{l}\text { No significant effects in the proportion of carers with scores of } \\
C E S-D \geq 16 \text { (i.e. at risk of depression) between the intervention } \\
\text { and control groups }\end{array}$ \\
\hline & & Well-being & $\begin{array}{l}\text { Modified GWB } \\
\text { Scale }\end{array}$ & $\begin{array}{l}\text { Significant positive changes in the GWB over time ( } p=0.004) \\
\text { between the intervention and control groups }\end{array}$ \\
\hline \multirow[t]{12}{*}{$\begin{array}{l}\text { Nichols } \\
\text { et al., [30] }\end{array}$} & \multirow{5}{*}{$\begin{array}{l}\text { Clinical translation } \\
\text { (uncontrolled before } \\
\text { and after study) }\end{array}$} & Burden & $\begin{array}{l}\text { Zarit Burden } \\
\text { Interview }\end{array}$ & No significant effects $(p>0.05)$ \\
\hline & & Bother with behaviours & RAM & $\begin{array}{l}\text { Significant positive changes in the burden over time } \\
(p=0.004)\end{array}$ \\
\hline & & Caregiving difficulties & & No significant effects $(p>0.05)$ \\
\hline & & Caregiving frustrations & & Significant positive changes over time $(p=0.004)$ \\
\hline & & Depression & $\begin{array}{l}\text { Patient Health } \\
\text { Questionnaire }\end{array}$ & Significant positive changes over time $(p=0.009)$ \\
\hline & \multirow[t]{7}{*}{$67 \%$} & Impact of depression & RAM & Significant positive changes over time $(p=0.01)$ \\
\hline & & Health behaviours & & No significant effects $(p>0.05)$ \\
\hline & & Health status & $\begin{array}{l}\text { Medical } \\
\text { Outcomes Study } \\
\text { Short-Form } 36\end{array}$ & \\
\hline & & Self-Care/safety & RAM & \\
\hline & & Social Support & & \\
\hline & & Hours on duty, & & \\
\hline & & Hours providing care & & \\
\hline \multirow[t]{4}{*}{$\begin{array}{l}\text { Fortinsky } \\
\text { et al., [31] }\end{array}$} & \multirow[t]{2}{*}{$\begin{array}{l}\text { Non-equivalent control } \\
\text { group }\end{array}$} & Burden & $\begin{array}{l}\text { Short Zarit } \\
\text { Burden Interview }\end{array}$ & \multirow{2}{*}{$\begin{array}{l}\text { No statistically significant changes between the intervention } \\
\text { and control groups in any of the median outcome measure } \\
\text { scores over time }(p>0.05)\end{array}$} \\
\hline & & $\begin{array}{l}\text { Community support } \\
\text { service use self-efficacy }\end{array}$ & $\begin{array}{l}\text { Likert type 10- } \\
\text { point score } \\
\text { questionnaire }\end{array}$ & \\
\hline & \multirow[t]{2}{*}{$68 \%$} & Depressive symptoms & CES-D & \multirow{2}{*}{$\begin{array}{l}\text { No statistically significant changes between the intervention } \\
\text { and control groups in any outcome measures after adjusting } \\
\text { for the three time points }(p>0.05)\end{array}$} \\
\hline & & $\begin{array}{l}\text { Symptom management } \\
\text { self-efficacy }\end{array}$ & $\begin{array}{l}\text { Likert type 10- } \\
\text { point score } \\
\text { questionnaire }\end{array}$ & \\
\hline \multirow{4}{*}{$\begin{array}{l}\text { Rodriguez- } \\
\text { Sanchez } \\
\text { et al., [32] }\end{array}$} & \multirow[t]{2}{*}{$\mathrm{RCT}$} & Burden & $\begin{array}{l}\text { Zarit Burden } \\
\text { Interview }\end{array}$ & $\begin{array}{l}\text { No significant effects for the intervention group compared } \\
\text { with the control group }(p>0.05)\end{array}$ \\
\hline & & Mental health & GHQ -12 & $\begin{array}{l}\text { A significant reduction in GHQ-12 score for the intervention } \\
\text { group compared with the control group }(p=0.01)\end{array}$ \\
\hline & \multirow[t]{2}{*}{$89 \%$} & $\begin{array}{l}\text { Dysfunctional thoughts } \\
\text { about caregiving }\end{array}$ & $\begin{array}{l}\text { Losada } \\
\text { questionnaire }\end{array}$ & $\begin{array}{l}\text { Significant positive changes for the intervention group } \\
\text { compared with the control }(p=0.01)\end{array}$ \\
\hline & & Quality of life & $\begin{array}{l}\text { Ruiz and Baca } \\
\text { questionnaire }\end{array}$ & $\begin{array}{l}\text { No significant effects for the intervention group compared } \\
\text { with the control group }\end{array}$ \\
\hline
\end{tabular}

GP General practice, PC Primary care, PHC Primary Health Care, PPDC Proactive Primary Dementia Care, $R C T$ Randomized Controlled Trial CES-D Center for Epidemiological Studies Depression scale, CES-D >16; GHQ-12: General Health Questionnaire; GWB General Well-Being scale; Patient Health Questionnaire; RAM Risk appraisal measure questionnaire; RMBPC Revised Memory and Behavior Problems Checklist

Likert type 10-point score questionnaire (Created specifically for the project) 
for lack of conceptual clarity and definition [38]. Our findings support those of Acton and Kang [39] who showed in their meta-analysis that only multifaceted interventions significantly reduced carer burden. They suggest that carer burden is such a broad concept that interventions may not consistently have any impact on it.

The fact that no studies were found investigating supportive interventions for carers of stroke survivors is surprising given the evidence that these carers regard general practice as an important source of support $[8,40]$. This suggests that general practice is possibly either offering little support directed at these carers or that evaluations of the interventions are not being published in peer reviewed journals. Either way, clearly more needs to be known about this given the potentially significant role general practice could play in supporting this important group.

The interventions were mainly intended to alleviate carers' psychosocial distress and consisted primarily of information and educational materials aimed at helping carers manage the behavioural challenges the person with dementia might display. These interventions focused on providing information to carers about the progression or manifestation of the disease and its management, whilst some interventions also aimed to address personal needs by providing support, skill training, and problem-solving. However, these publications did not always provide sufficient information to allow replication of the intervention and with the exception of Nichols et al. [30], the theoretical basis was not always clear. Furthermore, the evaluations did not provide enough detail to allow identification of the ideal timing of the interventions in relation to the stage of dementia. This is important given the dynamic nature of caring and the often downward trajectory in dementia caring [12].

The vast majority of the carer participants here were female. This finding has been reported elsewhere $[8,41]$. However, although female carers generally outnumber male carers [42] they are over-represented in carer intervention studies [43] which may be a significant issue given the evidence that male and female carers often describe different challenges. For example, male carers report less burden than female carers [44] and are also more likely to adopt task-orientated than emotionfocussed strategies [45]. This suggests that male and female carers are are likely to require different types of supportive interventions [46]. Future research should therefore address this to ensure that the interventions are appropriate for both male and female carers.

However, there are also some limitations of the review. Firstly, very few studies were identified limiting our potential conclusions. In order to ensure specificity of the review we did not include studies where the interventions were provided by professionals working outside general practice. These are listed in Additional file 1 but include, for example, interventions provided by social workers [47] or volunteers [41]. All the included studies were written in English, situated in the Western world and therefore potentially excluded some important cultural differences in the outcomes. Family caring has strong cultural influences [48] suggesting that interventions in one cultural group may not be suitable for other cultural groups. Publication bias is another concern in that studies with significant findings are more likely to be published and the dearth of qualitative studies may reflect this bias. The overall quality and the generalis ability of the included studies were variable, so the findings of the present research should be interpreted with caution. Finally we were also unable to find any studies investigating the efficacy of interventions for carers of people living with stroke and future reviews should address this by searching the grey literature.

\section{Conclusions}

In order to understand better the effect of interventions based in general practice, future research should perhaps also adopt mixed methods approaches which should make it possible to explore, for example, intervention acceptability. A health economic perspective to improve understanding of the cost-effectiveness of these varied interventions and programmes would also be an important addition. Further research is also needed to investigate and to clarify the timing and or the support needs carers of stroke survivors [49]. Finally, given the mixed findings of the effectiveness of these interventions for carers in both the general practice and more widely, greater user involvement in developing such interventions may be one means of improving their acceptability, with an impact on attrition and an increased chance of them benefitting both carers and ultimately those they care for.

\section{Additional file}

Additional file 1: Studies excluded in the last stage of the screening process. (DOCX $25 \mathrm{~kb}$ )

Competing interests

The authors declare that they have no competing interests.

Authors' contributions

$N G, F P$ and $A M H$ developed and refined the research questions and the protocol. FP performed the literature searches and $\mathrm{NG}$ and $\mathrm{AMH}$ examined abstracts and full-text articles of citations for eligibility. All authors drafted and approved the final manuscript.

\section{Acknowledgements}

The authors are grateful to the Faculty of Health, Social Care and Education, Kingston University and St George's University of London for funding this review.

Received: 22 October 2015 Accepted: 24 December 2015

Published online: 15 January 2016 


\section{References}

1. Feigin VL, Forouzanfar MH, Krishnamurthi R, Mensah GA, Connor M, Global Burden of Diseases, Injuries, and Risk Factors Study 2010 (GBD 2010) and the GBD Stroke Experts Group, et al. Global and regional burden of stroke during 1990-2010: findings from the Global Burden of Disease Study 2010. Lancet. 2014:383(9913):245-54.

2. Larson EB, Yaffe K, Langa KM. New insights into the dementia epidemic. N Engl J Med. 2013;369(24):2275-7.

3. Alzheimer's Association. Alzheimer's disease facts and figures. Alzheimers Dement. 2012;8(2):131-68.

4. Brereton L, Carroll C, Barnston S. Interventions for adult family carers of people who have had a stroke: a systematic review. Clin Rehabil. 2007; 21(10):867-84.

5. Department of Health. The National Stroke Strategy. London: DH; 2007. http://webarchive.nationalarchives.gov.uk/20130107105354/http://www.dh. gov.uk/en/Publicationsandstatistics/Publications/ PublicationsPolicyAndGuidance/DH_081062. Accessed 20 Oct 2015.

6. Cameron Jl, Naglie G, Silver FL, Gignac MA. Stroke family caregivers' support needs change across the care continuum: a qualitative study using the timing it right framework. Disabil Rehabil. 2013;35(4):315-24

7. Eldred C, Sykes C. Psychosocial interventions for carers of survivors of stroke: a systematic review of interventions based on psychological principles and theoretical frameworks. Br J Health Psychol. 2008;13(Pt 3):563-81.

8. Greenwood N, Mackenzie A, Cloud GC, Wilson N. Informal carers of stroke survivors - factors influencing carers: a systematic review of quantitative studies. Disabil Rehabil. 2008;30(18):1329-49.

9. Quinn K, Murray C, Malone C. Spousal experiences of coping with and adapting to caregiving for a partner who has a stroke: a meta-synthesis of qualitative research. Disabil Rehabil. 2014:36:185-98.

10. National Audit Office. Improving Services and Support for People with Dementia. London: National Audit Office; 2007. http://www.nao.org.uk/ report/improving-services-and-support-for-people-with-dementia/. Accessed 20 Oct 2015.

11. Perry $L$, Middleton $S$. An investigation of family carers' needs following stroke survivors' discharge from acute hospital care in Australia. Disabil Rehabil. 2011;33:1890-900.

12. Ory MG, Hoffman 3rd RR, Yee JL, Tennstedt S, Schulz R. Prevalence and impact of caregiving: a detailed comparison between dementia and nondementia caregivers. Gerontologist. 1999;39(2):177-85.

13. Schoenmakers B, Buntinx F, DeLepeleire J. Supporting the dementia family caregiver: the effect of home care intervention on general well-being. Aging Ment Health. 2010;14(1):44-56.

14. Selwood A, Johnston K, Katona C, Lyketsos C, Livingston G. Systematic review of the effect of psychological interventions on family caregivers of people with dementia. J Affect Disord. 2007:101(1-3):75-89.

15. Zarit S, Femia E. Behavioral and psychosocial interventions for family caregivers. Am J Nurs. 2008;108(9 Suppl):47-53. quiz 53.

16. Vernooij-Dassen M, Draskovic I, McCleery J, Downs M. Cognitive reframing for carers of people with dementia. Cochrane Database Syst Rev. 2011;11, CD005318.

17. Maayan N, Soares-Weiser K, Lee H. Respite care for people with dementia and their carers. Cochrane Database Syst Rev. 2014;1, CD004396.

18. Forster A, Brown L, Smith J, House A, Knapp P, Wright JJ, et al. Information provision for stroke patients and their caregivers. Cochrane Database Syst Rev. 2012;2, CD001919.

19. Visser-Meily A, Post M, van de Port I, van Heugten C, van den Bos T. Psychosocial functioning of spouses in the chronic phase after stroke: improvement or deterioration between 1 and 3 years after stroke? Patient Educ Couns. 2008;73(1):153-8.

20. Schoenmakers B, Buntinx F, Delepeleire J. What is the role of the general practitioner towards the family caregiver of a community-dwelling demented relative? A systematic literature review. Scand J Prim Health Care. 2009;27(1):31-40

21. Robinson L, lliffe S, Brayne C, Goodman C, Rait G, Manthorpe J, et al. Primary care and dementia: 2 Long-term care at home: psychosocial interventions, information provision, carer support and case management. Int J Geriatr Psychiatry. 2010;25(7):657-64.

22. O'Connor C. Caring for dementia carers: the role of general practitioners in Ireland. Ir J Med Sci. 2011;180(2):327-32.
23. Brotheridge S, Young J, Dowswell G, Lawler J, Forster A. A preliminary investigation of patient and carer expectations of their general practitioner in longer-term stroke care. J Eval Clin Pract. 1998;4(3):237-41.

24. Greenwood N, Mackenzie A, Harris R, Fenton W, Cloud G. Perceptions of the role of general practice and practical support measures for carers of stroke survivors: a qualitative study. BMC Fam Pract. 2011:12:57.

25. Moher D, Liberati A, Tetzlaff J, Altman DG, PRISMA Group. Preferred reporting items for systematic reviews and meta-analyses: the PRISMA statement. Ann Intern Med. 2009;151(4):264-9. W64.

26. Greenwood N, Pelone F, Hassenkamp AM. General practice based interventions/strategies to support carers of people with stroke or dementia. PROSPERO 2015:CRD42015016796. http://www.crd.york.ac.uk/prospero/ display record.asp?ID=CRD42015016796. Accessed on 20 Oct 2015.

27. European Academy of Teachers in General Practice (EURACT). European Definition of General Practice/Family Medicine. http://www.woncaeurope. org/gp-definitions. Accessed on 20 Oct 2015.

28. Kmet LM, Lee RC, Cook LS. Standard quality assessment criteria for evaluating primary research papers from a variety of fields. Alberta Herit Found Med Res. 2004:13:1-11.

29. Burns R, Nichols LO, Martindale-Adams J, Graney MJ, Lummus A. Primary care interventions for dementia caregivers: 2-year outcomes from the REACH study. Gerontologist. 2003;43(4):547-5.

30. Nichols LO, Martindale-Adams J, Burns R, Graney MJ, Zuber J. Translation of a dementia caregiver support program in a health care system-REACH VA. Arch Intern Med. 2011;171(4):353-9.

31. Fortinsky RH, Delaney C, Harel O, Pasquale K, Schjavland E, Lynch J, et al. Results and lessons learned from a nurse practitioner-guided dementia care intervention for primary care patients and their family caregivers. Res Gerontol Nurs. 2014;7(3):126-37.

32. Rodriquez-Sanchez E, Patino-Alonso MC, Mora-Simón S, Gómez-Marcos MA, Pérez-Peñaranda A, Losada-Baltar A, et al. Effects of a psychological intervention in a primary health care center for caregivers of dependent relatives: a randomized trial. Gerontologist. 2013;53(3):397-406.

33. Belle S, Burgio L, Burns R, Coon D, Resources for Enhancing Alzheimer's Caregivers' Health (REACH) II Investigators, et al. Enhancing the quality of life of dementia caregivers from different ethnic or racial groups: a randomized, controlled trial. Ann Intern Med. 2006;145(10):727-38.

34. Effective Practice and Organisation of Care (EPOC). [Suggested risk of bias criteria for EPOC reviews]. EPOC Resources for review authors. Oslo: Norwegian Knowledge Centre for the Health Services; 2015. http://epoc.cochrane.org/ epoc-specific-resources-review-authors. Accessed on 20 Oct 2015.

35. Zarit SH, Reever KE, Bach-Peterson J. Relatives of the impaired elderly: correlates of feelings of burden. Gerontologist. 1980;20(6):649-55.

36. Bedard M, Molloy DW, Squire I, Dubois S, Lever JA, O'Donnell M. The Zarit Burden Interview: A new short version and screening version. Gerontologist. 2001;41:652-7

37. Smits $\mathrm{CH}$, de Lange J, Dröes RM, Meiland F, Vernooij-Dassen M, Pot AM Effects of combined intervention programmes for people with dementia living at home and their caregivers: a systematic review. Int J Geriatr Psychiatry. 2007;22(12):1181-93.

38. Bastawrous M. Caregiver burden-a critical discussion. Int J Nurs Stud. 2013; 50(3):431-41.

39. Acton GJ, Kang J. Interventions to reduce the burden of caregiving for an adult with dementia: a meta-analysis. Res Nurs Health. 2001;24(5):349-60.

40. Simon C, Kendrick T. Informal carers-the role of general practitioners and district nurses. Br J Gen Pract. 2001;51(469):655-7.

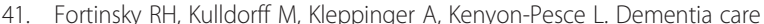
consultation for family caregivers: collaborative model linking an Alzheimer's association chapter with primary care physicians. Aging Ment Health. 2009;13(2):162-70.

42. White C. 2011 census analysis: unpaid care in England and Wales, 2011 and comparison with 2001. London: Office for National Statistics; 2013.

43. Greenwood N, Smith R. Barriers and facilitators for male carers in accessing formal and informal support: A systematic review. Maturitas. 2015;82(2):162-9.

44. Pinquart M, Sörensen S. Ethnic differences in stressors, resources, and psychological outcomes of family caregiving: a meta-analysis. Gerontologist. 2005:45(1):90-106.

45. Etters L, Goodall D, Harrison BE. Caregiver burden among dementia patient caregivers: a review of the literature. J Am Acad Nurse Pract. 2008;20(8):423-8 
46. Pinquart M, Sörensen S. Helping caregivers of persons with dementia: which interventions work and how large are their effects? Int Psychogeriatr. 2006;18(4):577-95.

47. Cherry DL, Vickrey BG, Schwankovsky L, Heck E, Plauchm M, Yep R. Interventions to improve quality of care: the Kaiser Permanente-alzheimer's Association Dementia Care Project. Am J Manag Care. 2004;10(8):553-60.

48. Greenwood N, Habibi R, Smith R, Manthorpe J. Barriers to access and minority ethnic carers' satisfaction with social care services in the community: a systematic review of qualitative and quantitative literature. Health Soc Care Community. 2015;23(1):64-78.

49. Cameron Jl, Gignac MA. "Timing It Right": a conceptual framework for addressing the support needs of family caregivers to stroke survivors from the hospital to the home. Patient Educ Couns. 2008;70(3):305-14.

Submit your next manuscript to BioMed Central and we will help you at every step:

- We accept pre-submission inquiries

- Our selector tool helps you to find the most relevant journal

- We provide round the clock customer support

- Convenient online submission

- Thorough peer review

- Inclusion in PubMed and all major indexing services

- Maximum visibility for your research

Submit your manuscript at www.biomedcentral.com/submit
) Biomed Central 